\title{
KNOWLEDGE TRANSFER AS ONE OF THE FACTORS OF INCREASING UNIVERSITY COMPETITIVENESS
}

\author{
Madina Bazarova $^{1}$, Waldemar Wojcik ${ }^{2}$, Gulnaz Zhomartkyzy ${ }^{3}$, Saule Kumargazhanova ${ }^{3}$, Galina Popova $^{3}$ \\ ${ }^{1}$ D. Serikbayev East Kazakhstan State Technical University, School of Information Technology/Department of Mathematical and Computer Modeling, Ust-Kamenogorsk, \\ Kazachstan, ${ }^{2}$ Lublin University of Technology, Institute of Electronics and Information Technology, Lublin, Poland, ${ }^{3}$ D. Serikbayev East Kazakhstan State Technical University, \\ School of Information Technology/Department of Information Technology, Ust-Kamenogorsk, Kazachstan
}

Abstract. The paper deals with university knowledge transfer. The adjustment of relations between universities and enterprises makes knowledge transfer a necessary requirement for university development to ensure the implementation of market-oriented educational programs. The paper proposes use of modular competency-based and ontological approaches to ensure the university knowledge transfer. The initial data is presented in the databases of the university, authorized bodies of education and science, enterprises, business structures and professional standards. This data is processed and scanned for knowledge to be put into the knowledge database with technological (informational) and modular competency-based approaches. As part of a market-oriented innovation university concept the task is to improve the education system in relation to skills development. To solve this problem it is necessary to build a distributed information system of university knowledge transfer. It is necessary to create a unified educational space - an educational portal - to ensure the university knowledge transfer between all participants - teachers, students and employers. The study offers an architectural solution for a distributed information system.

Keywords: educational programs, competence, ontology, distributed information systems

\section{TRANSFER WIEDZY JAKO JEDEN Z CZYNNIKÓW ZWIĘKSZANIA KONKURENCYJNOŚCI UNIWERSYTETU}

\begin{abstract}
Streszczenie. Artykut dotyczy transferu wiedzy uniwersyteckiej. Dostosowanie relacji między uniwersytetami a przedsiębiorstwami sprawia, że transfer wiedzy jest niezbędnym warunkiem rozwoju uniwersytetów, aby zapewnić realizację programów edukacyjnych zorientowanych na rynek. W artykule zaproponowano zastosowanie modułowego podejścia opartego na kompetencjach i ontologii, aby zapewnić transfer wiedzy uniwersyteckiej. Wstępne dane sa prezentowane $w$ bazach danych uniwersytetu, upoważnionych organów oświaty $i$ nauki, przedsiębiorstw, struktur biznesowych $i$ standardów zawodowych. Dane te sa przetwarzane $i$ skanowane $w$ celu umieszczenia wiedzy $w$ bazie wiedzy za pomoca technologicznych (informacyjnych) $i$ modułowych podejść opartych na kompetencjach. W ramach zorientowanej rynkowo koncepcji uniwersytetów innowacyjnych zadaniem jest ulepszenie systemu edukacji w odniesieniu do rozwoju umiejętności. Aby rozwiazać ten problem, konieczne jest zbudowanie rozproszonego systemu informacji o transferze wiedzy uniwersyteckiej. Konieczne jest stworzenie jednolitej przestrzeni edukacyjnej - portalu edukacyjnego - aby zapewnić transfer wiedzy uniwersyteckiej między wszystkimi uczestnikami - nauczycielami, studentami i pracodawcami. Badanie oferuje rozwiazanie architektoniczne dla rozproszonego systemu informatycznego.
\end{abstract}

Slowa kluczowe: programy edukacyjne, kompetencje, ontologia, rozproszony system informacyjny

\section{Introduction}

The Bologna process gave impetus to the improvement of higher professional education in Kazakhstan. Based on the concept of a market-oriented innovative university it is necessary to improve education system which involves development of skills in accordance with the global economy needs. For high-quality training of specialists who will be ready to work in a dynamically changing economic environment it is necessary to provide graduates with not only knowledge, but also a set of competencies which requires changes in their training.

Changes in the direction, goals, content and results of education are focused on individual development, creative initiative, student autonomy, competitiveness and mobility of future specialists [30]. Competence-based education comes to replace knowledge-based education, which provides a more comprehensive, personally and socially integrated educational result [1].

The concept of "knowledge management" appeared in 1990s $[9,20,26]$, but the problems of developing and implementing knowledge management systems at the lower infrastructural level remain relevant and critical for expanding the range of knowledge transfer participants. One approach to solve this problem is the development of a distributed information system for the university knowledge transfer which provides access to distributed knowledge databases of educational programs and scientific research through a semantic portal and program interfaces.

Knowledge is the most important resource of an organization. In this regard, organizations need to manage the knowledge they have, and this determines the relevance and importance of knowledge management and knowledge transfer.

One of the commonly used definitions of knowledge is the following: "Knowledge is a combination of data and information, opinions, skills and experience of experts are added, which results in a valuable asset that can be used when making decisions" $[27,29]$.

Each company and organization has accumulated huge amounts of information that needs to be processed and structured, that is, to be managed. The concept of "knowledge management" is relatively new, its general definition has not yet been formulated. This term is understood as a set of tools for knowledge accumulation, distribution, and exchange.

Knowledge management is a universal concept based on an integral approach to the creation, accumulation and storage of knowledge. In 1986, Karl Wiig introduced the concept of knowledge management.

At the turn of the 1980s - 1990s, three different approaches to the concept of "knowledge management" emerged in Sweden, the United States and Japan:

- "European approach" considers knowledge management from the standpoint of its measurement [25];

- "American approach" consists in direct "knowledge management" [28];

- "Japanese approach" focuses on "knowledge creation" [22].

From 1996 to the present, the knowledge management concept has been extended to all areas of activity including education and research [31].

Knowledge management technology is a set of processes, methods, techniques, software and technological tools to ensure knowledge exchange and creation. Scientists and business structures recognize the increasing role of professional knowledge [15].

The USA leads the knowledge management segment. Besides the United States, Germany, Great Britain, Scandinavia, India, Brazil and Australia are the most noticeable in this segment. 
Knowledge management allows integration of new management, marketing and information technology, innovative activity and creativity of people. It also provides a synergistic relationship between technological and behavioural aspects in management [8].

Using knowledge management systems organizations are able to determine the necessary explicit knowledge, tacit knowledge and the level of their distribution. Based on this, "knowledge is the subject of material culture embodied in specific people and in the relationship of these people and organizations," as stated in the paper by Lazareva A.V., Volkova E.A. [19].

There are two approaches to knowledge management:

- Personifying (intuitivist) approach;

- Technological (informational) approach.

The personifying (intuitive) approach is based on the fact that knowledge is contained in people. Employees are the key to knowledge management. This approach involves transfer of knowledge at meetings, trainings.

Technological (informational) approach is based on the fact that data is accumulated and stored in databases. But this data is not processed and not suitable for analysis. Information technologies are necessary for data search and processing, which makes it possible to reveal hidden dependencies and rules [16].

Based on the concept of a market-oriented innovative university it is necessary to improve education system which involves development of skills in accordance with the global economy needs. For high-quality training of specialists who will be ready to work in a dynamically changing economic environment it is necessary to provide graduates with not only knowledge, but also a set of competencies which requires changes in their training.

Fundamental changes in the model of higher educational institutions functioning took place in the Republic of Kazakhstan. These changes are due to the Strategy "Kazakhstan-2050" and the Bologna process; in accordance with this higher education institutions get the role of centres for "education, science, creativity, and knowledge transfer" [11, 23, 24].

The Republic of Kazakhstan supports the concept of a marketoriented innovative university, adopted by the leading world countries which is aimed at large-scale investment in human resources, development of professional competencies, and support for education system modernization to meet the global economy needs [10]. This requires the building a system called a knowledge transfer system [13].

Grudzinsky, A.O., Bedny, A.B. state in their article [12] that knowledge transfer means organizational systems and processes through which knowledge including technology, experience and skills is transferred from one side to the other leading to innovations in the economy and social sphere. The Bologna process determines the need to adjust the system. The adjustment of relations between universities and enterprises, which makes the knowledge transfer a necessary requirement the university development, will ensure the implementation of market-oriented educational programs.

Knowledge transfer is possible in an existing IT environment which provides knowledge accumulation, processing and sharing. Technological infrastructure covering national information resources, information resource sites (institutions) for technology transfer and knowledge management systems of companies, enterprises and educational institutions is a fundamental element of such an environment.

The problems of developing and implementing knowledge management systems at the lower infrastructural level remain relevant and critical for expanding the range of knowledge transfer participants. One approach to solve this problem is the development of a distributed information system for the university knowledge transfer which provides access to distributed knowledge databases of educational programs and scientific research through a semantic portal and program interfaces [4].
Knowledge transfer is more capacious than technology transfer. Knowledge transfer includes knowledge exchange between higher education institutions, businesses, government and public structures. A technology transfer is associated with commercialization of research results. The Republic of Kazakhstan technology transfer network is integrated with several national and international technology transfer networks. Among them there are Russian Technology Transfer Network, the Republican Centre for Technology Transfer (Belarus), the National Technology Transfer Network (Ukraine), Yet2Com American Innovation Exchange, the European Technology Transfer Market and the UNIDO database.

The paper proposes the use of modular competency-based and ontological approaches to ensure the university knowledge transfer. The initial data is presented in the databases of the university, authorized bodies of education and science, enterprises, business structures and professional standards.

This data is processed and scanned for knowledge to be put into the knowledge database with technological (informational) and modular competency-based approaches.

The modular competence-based approach to educational programs was studied by many researchers. However, the implementation of a mechanism for taking into account labour market needs and compliance of educational programs to national and international requirements for training specialists has not been fully studied.

The implementation of the modular competence-based approach will eliminate contradictions between education quality requirements imposed by the state, society, employers and training outcomes.

\section{Analysis of regulatory and informational support of educational programs development process in the RK universities}

At the moment, universities independently create educational programs content based on national qualification framework (undergraduate - graduate - Ph.D.) and a modular competencebased approach. A modular educational program (MEP) reflects goals, learning outcomes necessary to achieve these goals, and modules that ensure building competencies as a result of an academic process.

"Information and communication technologies" was chosen as professional activity field in our study. The RK draft professional standards for ICT occupations, the European Framework for ICT Competences (e-CF) and the European Certification System for ICT Specialists EUCIP were selected for this field. Based on this, an information model of university's distributed knowledge database has been built.

Professional standards which could be used to develop educational programs for training specialists at universities have not been fully developed in the Republic of Kazakhstan. "Zerde" Holding is developing 10 professional standards within the framework of "Information Kazakhstan - 2020" national program. There is a "National Qualifications System" chapter in the Labour Code of the Republic of Kazakhstan for the labour market.

The national qualifications system is a set of mechanisms for regulating supply and demand for qualifications of specialists in the labour market. The main goal of the national qualifications system is to create a flexible qualifilcations system in the Republic of Kazakhstan by regulating the interactions of education and the labour market. Its structure is shown in Fig. 1.

The national qualifications system is a combination of demand management mechanisms, it includes the national qualifications framework, the sectoral qualifications framework, professional standards and vocational training assessment.

Based on the national qualifications framework, professional standards are formed. A professional standard is a requirement for a level of qualifications, competencies, content, quality and working conditions for a specific area of professional activity. 


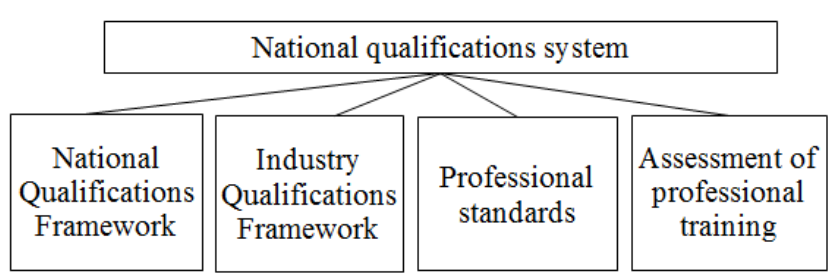

Fig. 1. The National Qualifications System structure

The sectoral qualifications framework (SQF) contains qualification levels. The SQF contains a structured description of qualification levels recognized in the sector which correspond to the National Qualifications Framework.

Based on professional standards, internal and corporate standards of organizations are developed for functional models of activity, positions, professional development, employee's formal evaluation, a labour incentives scheme, and others.

Professional standards define positions, qualification levels and job functions for each position. A labour function is a set of labour actions, which implies the existence of necessary competencies to perform a specific type of work activity.

A mechanism for taking into account the labour market needs, which is a part of an educational program concept, will make it possible to update requirements for professional activities, respond flexibly to changing environments, contribute to educational program development; it will increase the educational program quality and relevance in educational sphere.

The modular competence-based approach is used to implement a mechanism for correlating educational programs with the requirements of professional competencies to overcome the discrepancy between the state's, the society's and employers' requirements for education quality.

At present, the labour market requirements and comparability with national and international standards are not taken into account in university educational programs development.

Draft professional standards which are being developed by Zerde Holding will form national requirements of professional competencies for ICT personnel professional qualification. The European ICT Competence Framework (e-CF) and the European Certification System for ICT EUCIP specialists are used to meet international requirements for professional competencies.

The European framework for ICT competencies (TheEuropean e-CompetenceFramework, e-CF) is a framework for describing ICT competencies. e-CF can be used and recognized by companies producing ICT services and products and companies using ICT in their core business $[6,19]$.

Comparison of educational program competencies with national and international training requirements for ICT specialists requires expert evaluation. To solve this problem, it is necessary to build the information model of university distributed knowledge database.

The ontological approach allows combining the competencies of educational programs, professional standards and the requirements of international standards. Such an approach will allow transferring the requirements of professional competencies to the content of educational programs, which will increase the demand for university graduates in the national and international labour market.

An important function of the ontological model is the integration of heterogeneous data and knowledge in various fields of knowledge. The ontological model differs from the others, which are written using well-known tools and graphical languages: they are not separate models, but fragments of a common ontology $[4,21]$.

Our study proposes to create a distributed knowledge database. Ladyzhensky G. [18] described advantages of distributed knowledge databases and the method of their organization in detail. From the point of view of users and application programs, a distributed knowledge database looks like an ordinary local knowledge base, that is, distribution is invisible from the outside.
The information model of the distributed knowledge database of ICT university educational programs includes the ontology of the university's educational programs, the ontology of professional competencies in demand in the regional labour market, and the ontology of the European Framework for ICT Competences (e-CF).

The model of a distributed university knowledge database of ICT educational programs is a set of ontologies: ontology of university educational programs; professional standards ontology; ontology of the European framework of ICT competencies (e-CF).

The combination of educational program competencies, professional standards and e-CF form general training requirements necessary to perform a specific work activity. The educational standard competences are learning outcomes (competencies) of a modular educational program of the specialty. To achieve the result of training it is necessary to master certain modules that make up disciplines.

Competences of professional standards are labour functions which include knowledge and skills. The e-CF qualifications framework competencies are reference competencies that include knowledge and skills.

The ontological approach allows us to combine these three types of competencies and transfer professional competence into the content of disciplines, providing demand for graduates in the labour market without additional training or retraining.

\section{Architecture of a distributed information system of university knowledge transfer}

Within the framework of a market-oriented innovation university concept there is a task is to improve the system of education in relation to skills development. To solve this problem, it is necessary to build a distributed information system for university knowledge transfer (Fig. 2).

The participants in the university knowledge transfer are: students, applicants, teachers, researchers, employers, management staff, authorized education and science authorities and the administrator [2].

The general information model of a university distributed knowledge database includes ontology of the university educational programs, ontology of professional competencies in demand in the regional labour market, ontology of the European ICT Competences Framework (e-CF), and ontology of scientific knowledge. The ontology of scientific knowledge was developed earlier under grant "The development of an e-university's ontological knowledge base", state registration number 0213RK00305

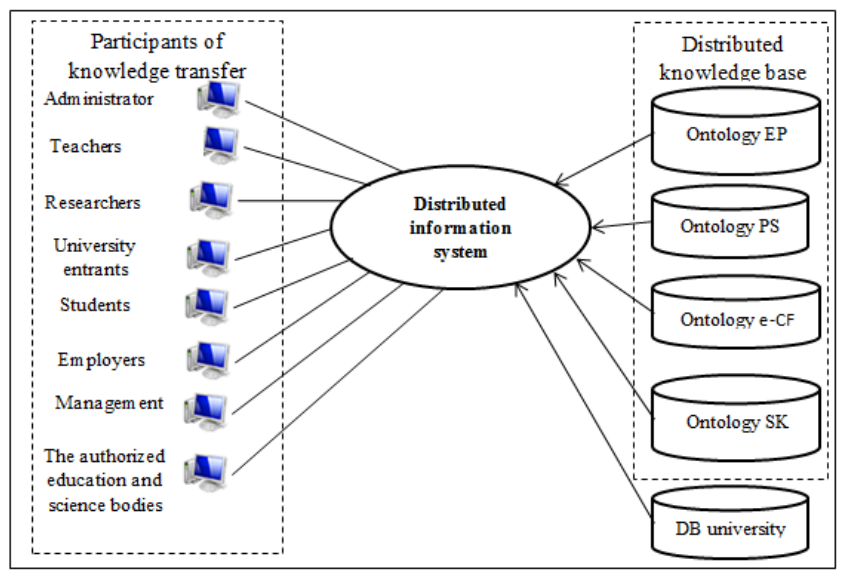

Fig. 2. Distributed IS

Distributed systems are client-server systems. The models of these systems and the advantages were considered in the study. A three-tier model is advantageous as the user interface is completely independent of the data processing component. 
The three-tier model includes a user interface component, a data management component (including databases), and middleware, which manages transactions and performs communication functions, transporting requests, managing names, and many other functions and is located between them. Middleware is the main component of distributed systems. The client explicitly requests one of the services provided by the application component. The client sends a request to the information bus, knowing nothing about the location of the service. For the client, the database is hidden by the services layer. Moreover, the client doesn't know anything about its existence at all, since all operations on the database are performed within services [18].

Service-oriented architecture is a set of services.

The architecture and the functional diagram of the distributed IS shown in Fig. 3 is based on a three-tier architecture and the use of services.

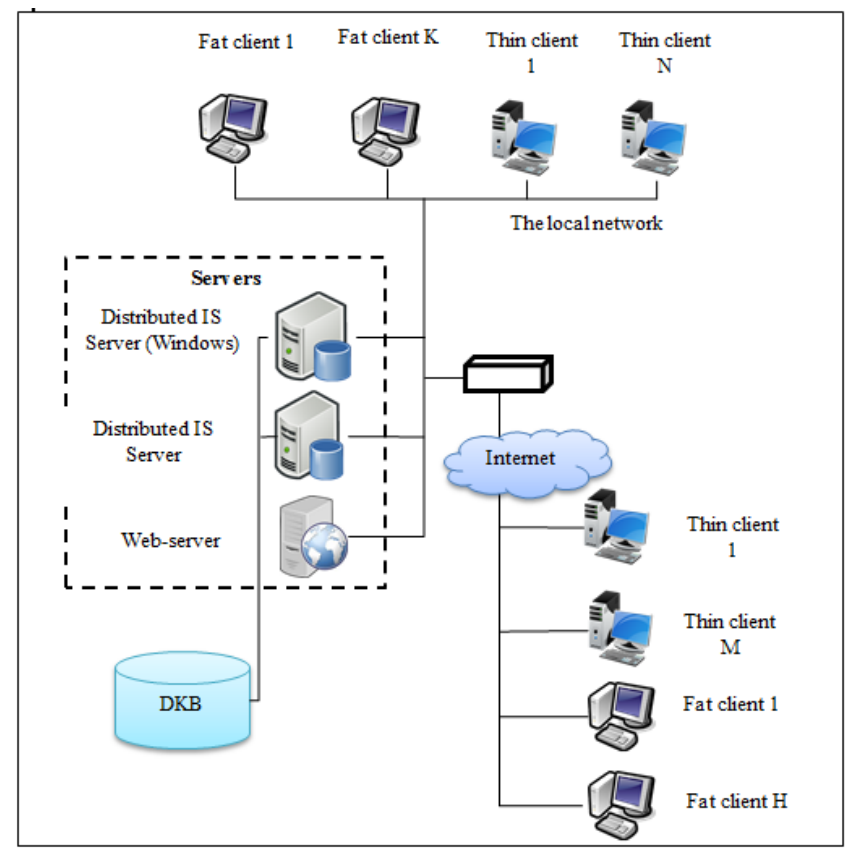

Fig. 3. Distributed IS Architecture

The main components are the distributed knowledge management system (DKMS), a web server, and an application server (middleware). To access and manage data, a thin or fat client link is used.

A "fat" client (as opposed to a "thin" client) is an application that provides enhanced functionality regardless of the central server. In this case, the server is often only used for data storage, and all the work on processing and presenting this data is transferred to the client's machine. A "thin" client is a computer or client program in networks with a client-server or terminal architecture that transfers all or most of the information processing tasks to the server. An example of a thin client is a computer with a browser used to work with web applications.

A distributed knowledge database involves storing and performing knowledge management functions in several nodes. Splitting data in a distributed database can be achieved by storing different tables on different computers or even storing different parts and fragments of the same table on different computers. The user does not see how knowledge is distributed between computers [17].

In the client-server mode, depending on the location of the software and the separation of functions, there are two types of work organization:

- "thin client" - "fat" server;

- "fat client" - "thin" server.
Placing application software on the client, i.e. "fat client" "thin" server, allows reducing the server's functionality to a minimum. The local software is located on the client machine, and the base software is located on the server. Transferring application software to the server, i.e. "thin client" - "fat" server, increases the network traffic. Both types can be organized both in a local network and in the Internet [14].

Windows server can be used for easy access to the local network. The knowledge database is located on another server for better security; it is recommended to use a Unix server.

Two servers are used to work with the knowledge database. A user has the opportunity to work with a distributed IS not only in the local network but also via the Internet, using a Web server. Local Area Network (LAN) support is used for access via a local area network. Web browser and network protocols are used for access via the Internet.

Let's look at the semantic educational portal as a prototype of a distributed information system for interacting with a distributed knowledge database [3].

A common educational space, i.e. educational portal is necessary to ensure the university knowledge transfer between all participants - teachers, students and employers.

The structure of the semantic educational portal is shown in Fig. 4. It is required to develop services for interaction with the knowledge database which combine technologies of working with the knowledge database and logical inference to access the knowledge contained in the distributed university knowledge database.

OWL API library is used for service interaction with distributed knowledge database. OWL API library has a modal structure and provides editing functions for the university distributed knowledge database and the inference engine operation.

HermiT will be used as an inference engine. The HermiT logic output machine supports the OWL DL standard more fully than Fact ++. The knowledge database consists of ontologies of educational programs, professional standards and the European ICT Framework - Competences (e-CF) (Fig. 4).

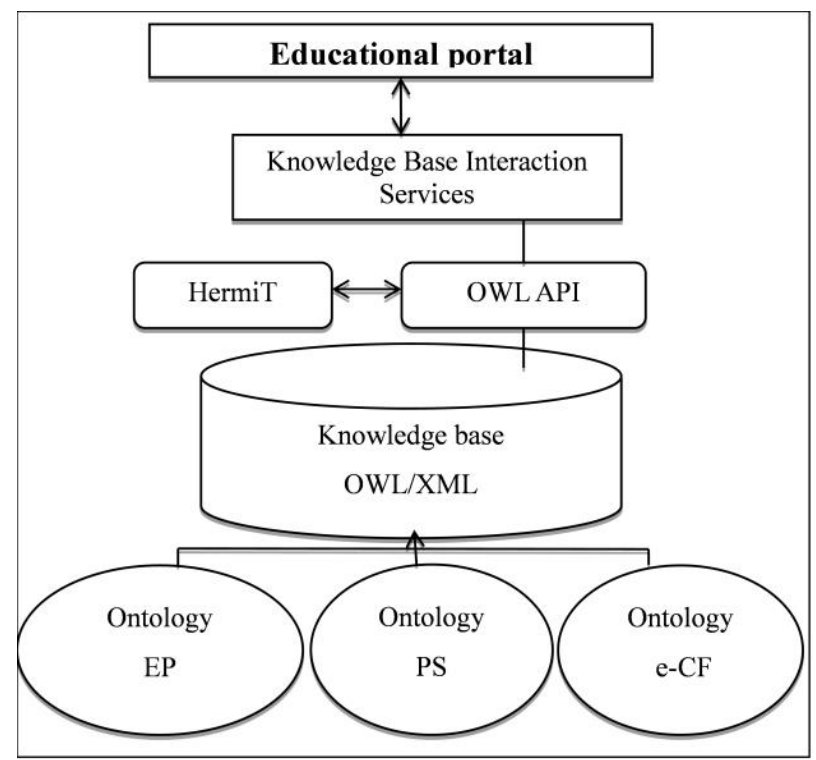

Fig. 4. The structure of a semantic educational portal

Layers forming the semantic educational portal services are shown in Fig. 5. The knowledge database structure of a serviceoriented system is stored on the server in the form of OWL / XML file. Access to the knowledge database is via web services. A library is used to edit the knowledge database. Search in the knowledge database functions are performed by the HermiT inference engine. Service generation functions and knowledge database search interface are performed on the client side. 


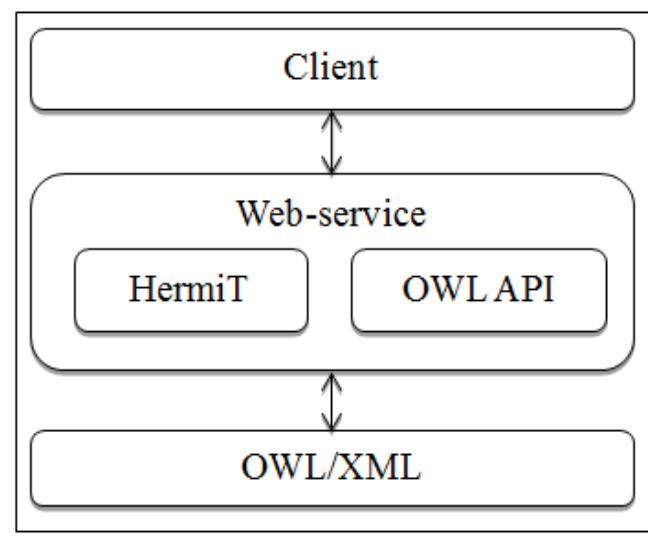

Fig. 5. Layers of services formation

The main components of the semantic educational portal being developed are: the ontology of knowledge representation, the ontology editor, a module for assessing the compliance of educational programs with professional requirements, a search and navigation subsystem for portal content, a distributed knowledge database. The relationship of the semantic educational portal components is shown in Fig. 6.

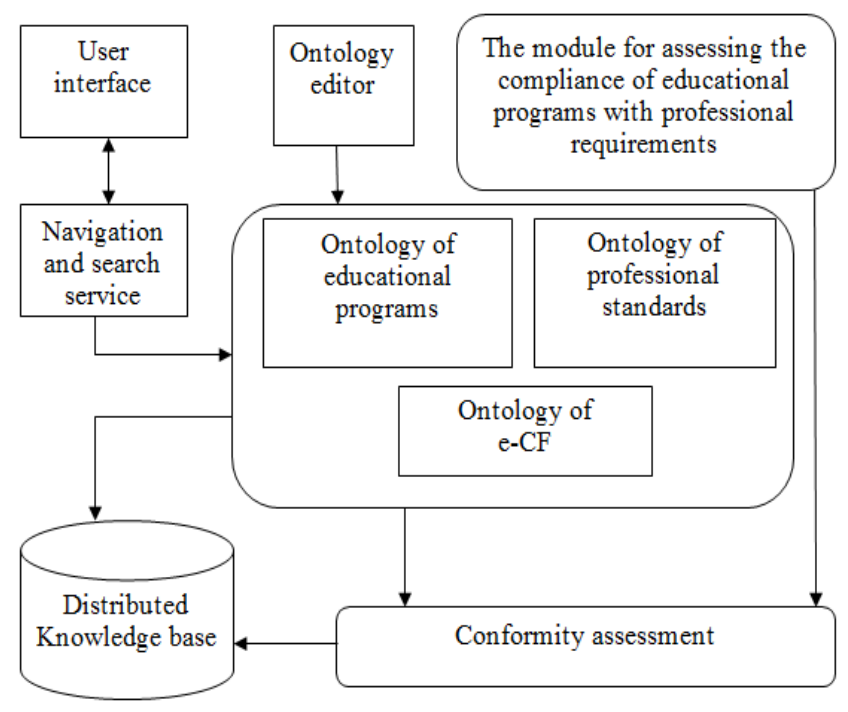

Fig. 6. The relationship of the semantic educational portal components

On the basis of the proposed portal composition model, a content-rich access to systematized knowledge and information resources of the modeled knowledge area is provided. This feature is provided by advanced navigation and search tools. The conformity assessment module ensures the compliance of educational programs with labor market professional requirements. The subsystem of the Microsoft Visual Studio 2017 in $\mathrm{C \#}$ expert system for assessing educational program quality is used as a module of conformity assessment. The ontological modeling subsystem includes the developed ontologies of educational programs, professional standards and e-CF.

\section{Conclusion}

An information model of the university's distributed knowledge base has been built up, including the ontology of the university's educational programs and the occupational competencies demanded on the regional labor market and the ontology of the university's scientific knowledge.

The method of analyzing hierarchies for posts has been approved. The obtained expert assessments will be used and included in the competence knowledge ontology database. This approach will allow students to build an individual learning trajectory aimed at obtaining concrete results necessary for performing interesting labor functions. The method of analyzing hierarchies allows examining the educational program in terms of learning outcomes and the requirements of labor functions.

The architecture of the distributed information system of knowledge transfer of higher educational institutions is presented. The user has the opportunity to work with distributed IP, not only in the local network, but also via the Internet, using the Web server. As a prototype of a distributed information system, to interact with a distributed knowledge base, the structure of the semantic educational portal is constructed.

The obtained results will be used for further development of the unified educational space of the university, including a distributed knowledge base, and built on the basis of the presented architecture and functional scheme of the distributed information system.

The study proposes an architectural solution of a distributed information system for the university knowledge transfer based on ontological models and logical methods of knowledge extraction. The architecture and functional diagram of the distributed information system are presented.

The structure of the semantic educational portal and the relationship of the semantic educational portal components are presented.

\section{References}

[1] Babanov N.Yu., Postalyuk N.Yu.: Modulno-kompetentnostnyy podkhod v rossiyskoy sisteme dovuzovskogo professionalnogo obrazovaniya: teoriya i praktika. Uchebnaya literatura, Samara 2006.

[2] Bazarova M., Zhomartkyzy G., Kumargazhanova S.: Using an Ontological Model for Transfer Knowledge Between Universities. Computational and Information Technologies in Science, Engineering and Education. UstKamenogorsk 2018, 34-43

[3] Bazarova M.Zh., Zhomartkyzy G., Wójcik W., Krak Yu.V.: Construction of individual trajectories of training specialists in the field of information and communication technologies. Journal of Automation and Information Sciences 49(10)/2017, 36-46 [DOI: 10.1615/JAutomatInfScien.v49.i10.40].

[4] Berners-Lee T., Hendler J., Lassila O.: The semantic web. Scientific American 284(5)/2001, 34-43.

[5] European framework for ICT Professionals in all industry sectors. http://www.ecompetences.eu/ (available 1.06.2019).

[6] Evropeyskaya ramka IKT-kompetentsiy 2.0. Ch. 1. Obshchaya evropeyskaya ramka kompetentsiy IKT-spetsialistov dlya vsekh sektorov industrii, 2014

[7] Furnye K.: Ot razrabotchika do rukovoditelya. Menedzhment dlya IT-spetsialistov. Mann. Ivanov i Feber, Moscow 2018.

[8] Fursov V.A., Lazareva N.V.: Upravleniye znaniyami kak effektivnyy instrument razvitiya sovremennogo transportno-logisticheskogo predpriyatiya 3/2011, 44-49.

[9] Gavrilova T.A., Khoroshevskiy V.F.: Bazy znaniy intellektualnykh sistem. Piter, Sankt Petersburg 2000

[10] Gorbunova E.M., Larionova M.V.: Evolyutsiya problematiki obrazovaniya v kontekste prioritetov i obyazatelstv «Gruppy vosmi». Logos, Moscow 2007 , 77-102.

[11] Gosudarstvennaya programma razvitiya obrazovaniya Respubliki Kazakhstan na 2011-2020, utverzhdena Ukazom Prezidenta Respubliki Kazakhstan ot 7.12.2010. Kazakhstanskaya Pravda 338/2010.

[12] Grudzinskiy A.O., Bednyy A.B.: Transfer znaniy - funktsiya innovatsionnogo universiteta. Vyssheye obrazovaniye v Rossii 9/2009, 66-71.

[13] Hagen S.: From Tech Transfer to knowledge exchange: European Universities in the Marketplace. Wenner-Gren International Series. Portland Press, London 2008, 103-117.

[14] Karpova I.P.: Issledovaniye i razrabotka podsistemy kontrolya znaniy v raspredelennykh avtomatizirovannykh obuchayushchikh sistemakh Dissertatsiya na soiskaniye zvaniya kand. tekhn. nauk po spetsialnosti 05.13.2013 MGIEM, Moscow 2002.

[15] Krymskaya A.: Khronologicheskaya shkala osnovnykh sobytiy $\mathrm{v}$ razvitii kontseptsii «upravleniya znaniyami» za rubezhom i v Rossii, http://www. kmtec.ru/publications/library/select/chron_km.shtml (available 1.06.2019).

[16] Kudryavtsev D.: Mnogogrannost upravleniya znaniyami na predpriyatii. BIGPeterburg 2004.

http://big.spb.ru/publications/bigspb/km/mnogogr_uz_na_predpr.shtml (available 1.06.2019).

[17] Kudryayev V.A., Korneyev I.K., Ksandopulo G.N.: Organizatsiya raboty s dokumentami. INFRA, Moscow 1999.

[18] Ladyzhenskiy G.: Raspredelennyye informatsionnyye sistemy i bazy dannykh, http://citforum.ru/database/kbd96/45.shtml (available 1.06.2019).

[19] Lazareva A.V., Volkova E.A.: Znaniye - strategicheskiy konkurentnyy resurs. Trudy Ulianovskogo nauchnogo tsentra Noosfernyye znaniya i tekhnologii 14/2011, 141-150.

[20] Milner B.Z.: Innovatsionnoye razvitiye: ekonomika. intellektualnyye resursy. upravleniye znaniyami. INFRA, Moscow 2009. 
[21] Mukhacheva N.N., Popov D.V.: Ontologicheskiye modeli i metody dlya upravleniya informatsionno-intellektualnymi resursami organizatsii. Vestnik UGATU 1(36)/2010, 123-135.

[22] Nonaka I., Takeuchi Kh.: Kompaniya-sozdatel znaniya. Zarozhdeniye $\mathrm{i}$ razvitiye innovatsiy $\mathrm{v}$ yaponskikh firmakh (The Knowledge-Creating Company: How Japanese Companies Create the Dynamics of Innovation) Olimp-Biznes, Moscow 2003.

[23] Poslaniye Prezidenta Respubliki Kazakhstan - Lidera natsii Nursultana Nazarbayeva narodu Kazakhstana «Strategiya «Kazakhstan-2050»: novyy politicheskiy kurs sostoyavshegosya gosudarstva» http://www.akorda.kz. 24.08.2014 (available 1.06.2019).

[24] Sopredsedatelstvo Respubliki Kazakhstan v Bolonskom protsesse: «Bolonskiye strukturnyye reformy: opyt. problemy i perspektivy». Kazakstannyn zhogargy mektebi. Vysshaya shkola Kazakhstana 1/2014.

\section{Ph.D. Madina Bazarova \\ e-mail: madina9959843@gmail.com}

Madina Bazarova Senior Lecturer, Department of Mathematical and Computer Modelling, School of Information Technology. She defended her doctoral thesis on "Distributed information system for transfer of knowledge of universities".

Scientific interests: Knowledge Management Ontology engineering, Semantic web, Artificial intelligence, Distributed information systems.

ORCID ID: 0000-0003-2580-6580

\section{Prof. Waldemar Wojcik}

e-mail: waldemar.wojcik@pollub.pl

Director of Institute of Electronic and Information Technologies, Faculty Electrical Engineering and Computer Science, Lublin University of Technology. Doctor of Technical Sciences, Professor.

Scientific interests: mathematical modelling, optica fibre in telecommunication systems and networks, electronic devices, Bragg fibre gratings, fibre optic sensors.

ORCID ID: 0000-0002-0843-8053

Ph.D. Gulnaz Zhomartkyz

e-mail: zhomartkyzyg@gmail.com

Zhomartkyzy Gulnaz Associate Professor of Information Technology, School of Information Technology.

Under her leadership are protected master theses and one doctoral thesis.

Scientific interests: Knowledge Management, Knowledge representation and reasoning, Ontology engineering, Semantic web, Artificial intelligence, Natural language processing.

ORCID ID: 0000-0003-1465-3451
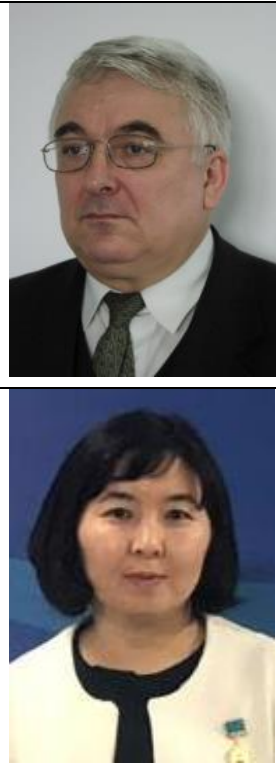

[25] Sveybi K.E.: Teoriya firmy osnovannaya na znaniyakh. Rukovodstvo k formulirovaniyu strategii. Intellektualnyy kapital 2(4)/2001

[26] Tuzovskiy A.F., Chirikov S.V., Yampolskiy V.Z.: Sistemy upravleniya znaniyami (metody i tekhnologii). Izd-vo NTL, Tomsk 2005.

[27] Tuzovskiy A.F.: Razrabotka sistem upravleniya znaniyami na osnove edinoy ontologicheskoy bazy znaniy. Izvestiya Tomskogo politekhnicheskogo universiteta - Inzhiniring georesursov 310(2)/2007, 182-185.

[28] Viig K.: Osnovy upravleniya znaniyami. Progress, Moscow 1986

[29] Zhomartkyzy G.: Upravleniye znaniyami kak faktor razvitiya vuza. Vestnik VKGTU 4/2016, 101-105.

[30] Zimnyaya I.A.: Klyuchevyye kompetentsii - novaya paradigma rezultata obrazovaniya. Eksperiment i innovatsii v shkole 2/2009, 7-14.

[31] Zubarev M.G.: Sravnitelnyy analiz zarubezhnykh podkhodov upravleniya znaniyami. Mezhdunarodnyy studencheskiy nauchnyy vestnik 3/2014, 1-6.

\section{Ph.D. Saule Kumargazhanova \\ e-mail: skumargazhanova@gmail.com}

Saule Kumargazhanova Associate Professor of Information Technology, School of Information Technology, Head of the sub-department.

Under her leadership are protected master theses.

Scientific interests: modelling information processes and systems, artificial intelligence, new communication technologies.

ORCID ID: 0000-0002-6744-4023

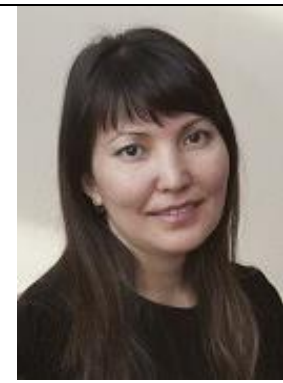

\section{Ph.D. Galina Popova \\ e-mail: gal_tomsk@mail.ru}

Galina Popova Associate Professor of Information Technology, School of Information Technology. Under her leadership are protected master theses. Scientific interests: modelling, artificial intelligence, new communication technologies.

ORCID ID: 0000-0002-7754-0828

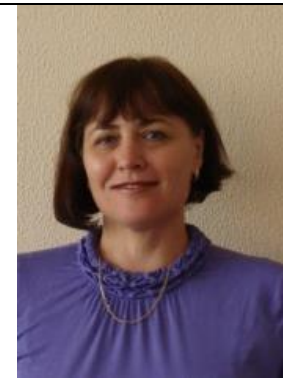

przyjęto do druku/accepted: 15.06 .2019 